\title{
Estetika Logo Magelang Kota Sejuta Bunga
}

\author{
Galih Putra Pamungkas ${ }^{1}$, Ahmad Adib Masruri² \& Titis Srimuda Pitana ${ }^{3}$
}

\author{
${ }^{1}$ Mahasiswa Pascasrjana Seni Rupa Universitas Sebelas Maret Surakarta, ${ }^{2,3}$ Dosen Pascasarjana Universitas \\ Sebelas Maret Surakarta \\ Universitas Sebelas Maret Surakarta \\ galih_cokrowardoyo@student.uns.ac.id
}

\begin{abstract}
In 2012, Magelang city proclaimed as the City of Million Flowers. An important element to keep brand awareness and public attention awake is the aesthetic element. The main visual form is the logo. Logo is a visual identity that reflects from the vision, mission of the organization, the company, the city or personality. The logo can not yet be said to represent the philosophy of Magelang City Million Flowers. The aesthetic element of the logo does not reflect the philosophy of the city branding program. The aesthetic element of logo weight is less strong. The message conveyed is less clear because of the influence of the element of the form that is less precise, the subject color and the placement of writing a million flowers that require small font size, so the legibility is low. The aesthetic element of logo appearance is less maximize the type of promotion media, so the communication process is hampered.

This research analyzes the aesthetics of Magelang City logo's with tagline Magelang City of Million Flowers through qualitative method. The theory of aesthetics used is a theory written by AAM. Djelantik in 1999, regarding the three major elements in aesthetics: form, weight, and appearance.
\end{abstract}

Keywords: Aesthetic, Design, Communication and Visual

Relevance to Visual Communication Design Practice: This research is expected to add insight and perspective in the development of visual communication design science, which is the aesthetic and functional visual branding of the city.

\section{FORMAT NASKAH}

Sejak tahun 2012, Kota Magelang mencanangkan diri sebagai Kota Sejuta Bunga yang sekaligus menjadi brand baru dari Kota Magelang untuk mewujudkan kota jasa yang dikemas lebih menarik. Membangun citra sebuah kota tidak cukup dengan menciptakan slogan pun tidak cukup dengan membangun landmark atau simbol kota. Diperlukan upaya terintegrasi oleh seluruh pemangku kepentingan dan lapisan masyarakat untuk menampilkan dan memperkuat positioning (posisi bersaing) kota tersebut. Kemudian masih juga diperlukan upaya komunikasi yang strategis dan estetis untuk menyampaikan pesan agar efektif dan efisien (mix magz, September 2016:45). Visual branding adalah pengaruh yang diakibatkan oleh suatu bentuk visual untuk mendiferensiasikan brand. Diferensiasi artinya membedakan brand tersebutdari brand komp etitor, sehingga dapat terlihat dan dirasakan menonjol dibanding yang lain dan paling diingat audiensnya (Budiman, 2008:1). Brand yang dimaksud dalam kajian ini ialah kota, yang lebih khususnya ialah Kota Magelang. Dalam penggarapannya, visual branding sangat dipengaruhi oleh bentuk, warna, dan komposisi yang tentu saja disesuaikan dengan konsep brandingnya. Menurut Sumbo 
Tinarbuko (2015:79), untuk membantu agar pesan/brand mudah diingat perlu diimbangi dengan rancangan visual branding yang estetis yang dikomunikasikan melalui media periklanan, baik media lini atas (surat kabar, majalah, tabloid, radio, televisi, internet, telepon seluler) maupun media lini bawah (poster, brosur, flyer, merchandising, tas, baju, dan lain sebagainya) serta dalam bentuk brand activation.

Visual yang dimunculkan harus dapat mengidentifikasikan unsur dan atribut dasar yang paling sesuai yang dapat mengungkapkan keinginan yang ingin dicapai dari konsep branding kota. Bentuk visual yang paling utama ialah logo. Logo adalah identitas visual yang mencerminkan dari visi, misi suatu perusahaan/kota/pribadi. Logo merupakan suatu hal yang nyata sebagai pencerminan halhal yang bersifat non visual dari suatu perusahaan/kota/pribadi, misalnya budaya perilaku, sikap, kepribadian, yang dituangkan dalam bentuk visual (Suwardikun, 2000:7). Unsur utama yang diperhartikan dalam perancangan logo ialah unsur estetika. Secara umum estetika berhubungan dengan daya penglihatan. Pengamat dapat melihat secara rinci unsur-unsur desain yang ada. Estetika dapat dikatakan sebagai sesuatu yang menimbulkan rasa senang, rasa puas, rasa aman, rasa nyaman dan ketika rasa itu sangat kuat, manusia yang menyaksikannya akan terharu, terpaku, terpesona, serta menimbulkan keinginan mengalaminya. Atau dengan kata lain persepsi visual yang estetis akan menimbulkan reaksi dari yang mengamati, sehingga si pengamat akan terpengaruh, kemudian melakuan perbuatan dan menghasilkan sesuatu yang menjadi tujuan sebuah karya visual. Menurut Tri
Prasetyo Utomo (2015:63), dalam ranah desain, rasa estetika yang terdapat dalam karya desain di dasarkan pada elemen-elemen dan prinsip-prinsip perancangan yang dapat dijelaskan secara rasional. Persepsi visual dari elemen-elemen yang mendasari semua bermuara pada prinsip-prinsip estetika dan merupakan kebutuhan emosional yang vital, tapi merupakan penentu keberhasilan sebuah karya desain.

Sangat disayangkan jika program city branding yang bertujuan untuk memaksimalkan potensi yang dimiliki justru terhalang oleh tidak efektifnya proses komunikasi yang dilaksanakan. Salah satu proses komunikasi yang tidak efektif ialah proses komunikasi bentuk visual melalui media promosi. Melalui pendekatan estetika kajian ini bertujuan untuk menemukan permasalahan tidak maksimalnya proses komunikasi visual logo Kota Magelang yang memiliki tagline Magelang Kota Sejuta Bunga dan memberikan pemecahan masalah yang sesuai dengan kaidah estetika, sehingga proses komunikasi visual logo Kota Magelang dapat berjalan dengan efektif.

Penelitian ini menganalisis cara mengemas unsur Estetika logo Kota Magelang yang memiliki tagline Magelang Kota Sejuta Bunga melalui metode kualitatif dengan teknik pengumpulan data kepustakaan, observasi, dan wawancara. Teori estetika dalam penelitian ini ialah teori yang ditulis oleh AAM. Djelantik pada tahun 1999, sedangakan data tertulis lain yang menjadi acuan ialah masterplan Magelang Kota Sejuta Bunga. Narasumber dalam penelitian ini ialah pihak BAPEDA Kota Magelang yang diwakili oleh Bapak Sugeng. Observasi langsung dilakukan oleh peneliti di Kota Magelang 
untuk mendapatkan fakta-fakta di lapangan selama satu bulan di Bulan Desember 2017.

\section{PEMBAHASAN}

Di dalam estetika terdapat beberapa aliran, yaitu estetika filosofis-trandsendental, estetika formalistis, estetika rokhaniyah. Estetika formalistis yang menjadi fokus dalam kajian ini memiliki pengertian estetika yang menelaah berbagai aspek lahiriah karya desain sebagai obyek estetis. Menurut Djelantik (1999:15) dalam karya seni dan desain terdapat tiga unsur estetika yang paling menonjol.

\section{A. Wujud}

Wujud adalah bentuk yang tampak (dilihat atau didengar) dari sebuah karya desain. Unsur ini terdiri dari elemen-elemen visual seperti garis, titik, warna dan lain sebagainya. Dalam sebuah karya terdapat pengorganisasian bagian-bagian yang tersusun membentuk karya secara utuh. Terdapat tiga unsur struktur yang berperan menimbulkan rasa indah dalam sebuah karya.

1) Keutuhan (unity)

Menunjukkan hubungan yang relevan antara komponen yang satu dengan yang lain. Satu komponen dengan komponen yang lain saling mendukung dan membutuhkan, sehingga terjadi kekompakan antar komponen.

2) Penonjolan (dominance)

Mengarahkan perhatian pengamat sebagai subyek dalam menikmati sebuah karya seni maupun desain.

3) Keseimbangan (balance)

Keseimbangan biasa diperoleh dengan memanfaatkan unsur simetri maupun asimetri.

\section{B. Bobot}

Selain apa yang dapat dilihat dari sebuah karya desain, bobot juga meliputi apa yang bisa dirasakan dan dihayati sebagai makna dari wujud desain tersebut. Unsur ini meliputi suasana, gagasan dan pesan yang di komunikasikan

\section{Penampilan}

Penampilan ialah cara penyajian sebuah desain kepada target audiens. Salah satu unsur yang paling penting dalam penyajian desain ialah jenis media dan penempatan media (media placement).

Estetika dapat menimbulkan rasa senang, rasa puas, rasa aman, rasa nyaman dan ketika rasa itu sangat kuat, manusia yang menyaksikannya akan terharu, terpaku, terpesona, serta menimbulkan keinginan mengalaminya. Atau dengan kata lain persepsi visual yang estetis akan menimbulkan reaksi dari yang mengamati, sehingga si pengamat akan terpengaruh, kemudian melakuan perbuatan dan menghasilkan sesuatu yang menjadi tujuan sebuah karya visual. Artinya jika logo Kota Magelang unsur-unsur estetika terpenuhi maka proses komunikasi program city branding yang yang diwakilkan pada karya logo tersebut akan berjalan efektif sehingga yang menjadi tujuan program city branding tercapai.

Berikut unsur-unsur visual (Suparta, 2010:1-3).

1) Titik

Wujud titik relatif kecil dengan dimensi panjang dan lebar yang tidak berarti. Titik cenderung ditampilkan dalam bentuk 
berkelompok, dengan variasi jumlah, susunan dan kepadatan tertentu.

2) Garis dan bentuk

Garis dianggap memiliki banyak pengaruh dalam pembentukan suatu objek sehingga juga menjadi batas suatu bidang atau warna. Peran garis dan bentuk dalam media ialah: pemisah antar bagian, pengarah perhatian, manipulasi ruang, mendukung tampilan artistik.

3) Bidang

Bidang memiliki dimensi panjang dan lebar. Bidang dapat dihadirkan dengan menyusun titik maupun garis dengan kepadatan tertentu, dapat juga dihadirkan dengan mempertemukan potongan hasil goresan satu garis atau lebih.

4) Ruang

Ruang tercipta oleh adanya bidang. Pembagian bidang atau jarak antar objek berunsur titik, garis, bidang, dan warna. Ruang lebih mengarah pada perwujudan tiga dimensi sehingga ruang dapat dibagi dua, yaitu ruang nyata dan semu.

5) Warna

Keberadaan warna ditentukan oleh pigmennya. Kesan yang diterima oleh mata lebih ditentukan oleh cahaya. Peran-peran warna: memberikan kesan realistis, membangkitkan perhatian, memiliki bahasa psikologis untuk menguatkan mood pesan, meningkatkan tampilan artistik.

6) Tekstur

Tekstur adalah nilai raba dari suatu permukaan. Secara fisik, tekstur dibagi menjadi kasar dan halus, dengan kesan pantul kusam dan mengkilat. Dalam penerapannya, tekstur dapat berpengaruh terhadap unsur visual lainnya, yaitu kejelasan titik, kualitas garis, keluasan bidang dan ruang, serta intensitas warna.

7) Huruf

Hubungan antara huruf, kata, dan ide sangat erat. Huruf merupakan bagian dari kata, dan kata merupakan bagian dari sebuah ide. Pemilihan huruf dan kata yang baik dan menarik akan mendukung ide yang baik pula. Hal-hal yang perlu diperhatikan dalam pemilihan huruf.

8) Gambar

Gambar sering diibaratkan dapat berbicara sejuta kata. Penggunaannya perlu dipertimbangkan karena dapat menjalankan berbagai peran. Peran-peran tersebut: menjelaskan hal-hal yang sulit dijelaskan lewat kata-kata, meringkas pengertian, menarik dan mengarahkan perhatian, membantu mengekalkan ingatan, membangkitkan kesenangan, memberikan kesempatan mata beristirahat, mengisi ruang, meningkatkan tampilan artistik.

9) Bahan

Bahan merupakan wadah dimana unsurunsur visual diterapkan, sekaligus merupakan unsur visual yang cukup menentukan untuk berperan sebagai: memberikan citra, menguatkan pesan, menentukan mutu tampilan.

Pembangunan Magelang Kota sejuta Bunga akan diwujudkan meliputi pembangunan fisik, ekonomi, dan sosial budaya, melalui serangkaian program yang saling berkait dan dilaksanakan secara berkesinambungan. Sebagai salah satu pendukung promosi program tersebut, perlu dipikirkan adanya sebuah kesatuan bentuk visual sebagai pengikat pesan kepada khalayak yang dituju seperti yang sudah tertulis pada 
Peraturan Daerah Kota Magelang Nomor 11 Tahun 2014, tentang Branding Kota.



Gambar 1 Logo Magelang Kota Sejuta Bunga Sumber: www.magelangkota.go.id, Februari 2108

Berdasarkan buku manual logo Magelang Kota Sejuta Bunga, konsep kreatif logo terinspirasi dari sebuah taman yang terpapar sinar matahari pagi yang cerah, sehingga tampak indah. Logo tersebut memiliki makna Kota Magelang yang penuh harapan dan semangat terus maju. Bentuk visual logo ialah lingkaran matahari yang dikelilingi tujuh bunga dan dipadu padankan dengan teks Magelang Kota Sejuta Bunga. Secara keseluruhan warna dari logo ialah oranye.

Ketidaksesuaian logo dengan filosofi Magelang Kota Sejuta Bunga dapat menimbulkan makna yang berbeda, sehingga dapat menimbulkan pemaknaan berbeda dari masyarakat yang tidak sesuai dengan tujuan dari Magelang Kota Sejuta Bunga. Belum adanya patokan khusus ukuran minimal logo (grapich standart manual) ditempatkan juga merupakan kekurangan kelengkapan dalam buku manual logo Magelang Kota Sejuta Bunga, patokan ukuran penting untuk mengatur ukuran minimal logo ketika di pasang dalam berbagai media promosi, hal ini untuk menjaga kualitas logo tetap terjaga dan tingkat visibilitas logo dalam media promosi juga terjaga baik.

\section{A. WUJUD}

Logo Magelang Kota Sejuta Bunga memiliki bobot keseimbangan yang cenderung berat ke sisi kanan dari sudut pandang pengamat. Dengan konsep yang seperti itu logo, konsep semangat terus bergerak maju ke depan dapat terwakili. Sebuah bentuk visual terdiri dari unsur desain yang membentuk satu kesatuan yang utuh, seimbang dan harmonis, seperti warna, titik, garis, huruf dan lain sebagainya. Dalam masterplan Magelang Kota Sejuta Bunga, filosofi dari Kota Sejuta Bunga ialah magelang merupakan tempat yang sejuk, aman, tertib, bersih, indah, ramah dan kenangan yang kemudian diimplementasikan ke dalam logo yang diwakili oleh simbol 7 bunga yang bermakna sapta pesona pariwisata.

Dalam psikologi komunikasi warna merupakan salah satu stimulus dalam pesan visual yang mengirimkan sensasi melalui indera penglihatan manusia kemudian orang tersebut akan mempersepsikan pesan tersebut menggunakan ingatannya dan menghasilkan pikiran dan tindakan (Rakhmat, 2012:47-73). Secara keseluruhan warna yang ada dalam logo didominasi oleh gradasi unsur warna merah dan kuning yang menjadi oranye. Warna merah, oranye, dan kuning memiliki makna yang serumpun yakni, semangat, hangat, nyamaan, ceria dan optimis. Makna ini bisa dikatakan hanya mewakili filosofi logo yaitu semangat ke depan, artinya dilihat dari unsur warna makna filosifis lain belum terwakili. Kesan warna oranye saja dapat memberi makna Magelang kota yang panas, 
tentunya hal ini bertentangan dengan filosofis dan kondisi di magelang yang sejuk. Kesan satu unsur warna juga tidak menunjukkan sinergitas, keluesan dan kedamaian Kota Magelang yang terdiri dari berbagai jenis latar belakang masyarakatanya. Sebaiknya memang disematkan juga unsur warna lain seperti, hijau yang bermakna sejuk, ungu yang bermakna akrab dan aman, putih yang bermakna bersih dan magenta yang bermkana seimbang dan sehat. Warna-warni mendukung tagline Magelang Kota Sejuta Bunga itu sendiri, filosofi yang terkandung di dalamnya dan tentunya lebih menarik perhatian.

Dalam logo Magelang Kota Sejuta Bunga ada titik-titik di bunga sapta pesona yang terlalu rapat dan kecil, yang mungkin ditujukan mewakili sari bunga, namun dengan ukuran yang terlalu kecil seperti itu di khawatirkan akan tidak terpakai atau tidak telihat jika logo di tempatkan dalam ukuran kecil. Huruf yang digunakan pada kata sejuta bunga juga terlalu kecil, mungkin dikarenakan penempatannya, padahal tulisan sejuta bunga merupakan inti pesan visual branding Magelang Kota Sejuta Bunga. Ukuran yang terlalu kecil akan sangat sulit diterapkan pada media promosi berurukuran kecil, karena tingkat keterbacaan huruf yang kurang. Hal tersebut bisa dibenahi dengan menempatkan tulisan sejuta bunga di bawah tulisan magelang, sehingga ukuran huruf sejuta bunga bisa diperbesar. Jenis huruf yang digunakan ialah dekoratif yang tidak disebutkan jenisnya atau merupakan ciptaan sendiri atau menggunakan tipe huruf yang sudah tersedia.

\section{B. BOBOT}

Secara keseluruhan bobot dari logo Magelang Kota Sejuta Bunga memang belum bisa dikatakan mewakili secara menyeluruh apa yang menjadi visi misi Magelang Kota Sejuta Bunga, hal ini tidak lain karena unsurunsur pembentuk logo yang belum benarbenar sesuai dengan filosofi di bentuknya city branding Magelang Kota Sejuta Bunga. Ada jenis-jenis warna lain dalam Logo Magelang Kota sejuta Bunga yang bisa menunjukkan kontras yang mempertegas, memberikan penonjolan serta mewakili makna filosofis logo. Kontras juga menambah mutu estetik, sehingga lebih mudah menarik perhatian pengamat. Kata sejuta bunga pada logo tampak tidak sama kuat dengan unsur lainnya, padahal sejuta bunga merupakan inti pesan dari logo, penempatannya lah yang memaksa sejuta bunga harus dibuat dengan ukuran terlalu kecil.

\section{Penampilan}

Dalam buku manual logo Magelang Kota Sejuta Bunga, patokan ukuran tidak dicantumkan. Patokan ukuran penting untuk mengatur ukuran minimal logo ketika di pasang dalam berngai media promosi, hal ini untuk menjaga kualitas logo tetap terjaga dan tingkat visibilitas logo dalam media promosi juga terjaga baik. Implementasi logo dalam media promosi juga belum tampak. Menurut Sumbo Tinarbuko (2015:78-79), aplikasi perancangan dan perencanaan desain promosi senantiasa melibatkan seluruh media periklanan yang meliputi:

1) Media Lini Atas

a) Media Online

Saat ini masyarakat untuk mencari dan mendapatkan informasi ialah melalui media 
online, seperti website dan sosial media. Untuk itu selain konten yang lengkap, logo yang estetis juga harus terpampang untuk memberikan kesan yang baik mengenai kota, sehingga masyarakat tertarik untuk melakukan kunjungan. Kota Magelang belum memanfaatkan media online secara maksimal, walaupun sudah memiliki website dan aplikasi untuk smartphone, namun konten yang disajikan juga belum lengkap dan tidak selalu up to date terutama mengenai Magelang Kota Sejuta Bunga. Kota Magelang pada tanggal 28 Januari 2018 baru saja merilis tampilan baru website yang bisa di lihat di www.magelangkota.go.id.

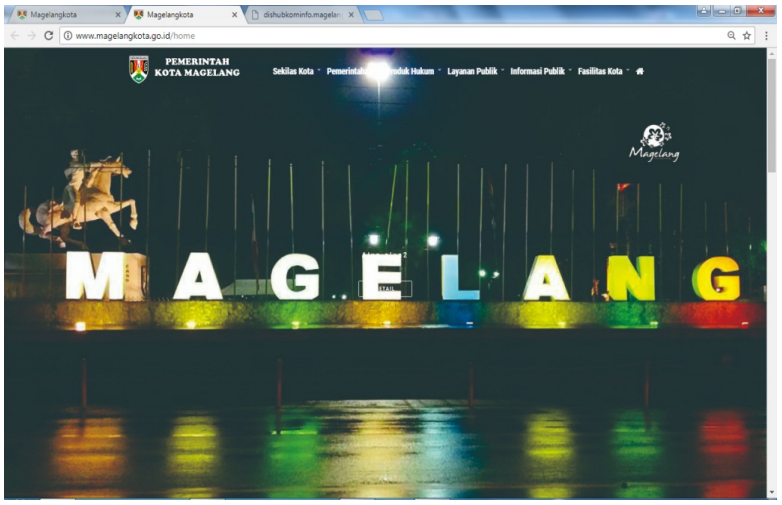

Gambar 2 Homepage website Kota Magelang Sumber: www.magelangkota.go.id, Februari 2018

Tampilan website terbaru tersebut menggunakan background video pada halaman depan yang menggambarkan sebuah acara di Alun-alun Kota yang diadakan malam hari dan terdapat link-link dalam bentuk tombol yang mengarah pada halamanhalaman berikutnya. Logo Magelang Kota Sejuta Bunga ditampilkan di halaman utama dengan warna putih dan background hitam. Logo ditempatkan di sisi kanan atas dari pengamat dengan kesan asal di perpampangkan. Background persegi pada logo tidak dihilangkan, sehingga memotong dan menutupi begitu saja bagian foto background. Logo tersebut juga ditampilkan dengan ukuran kecil sehingga tulisan sejuta bunga tidak terbaca dan tampak seperti garis saja. Logo sebagai bentuk visual utama pengikat pesan Magelang Kota Sejuta Bunga, seharusnya lebih diperlihatkan. Ukuran logo lebih diperbesar dan penempatan logo juga diperhatikan agar menonjol, seimbang dan kesatuan dari keseluruhan tampilan halaman website tercapai.

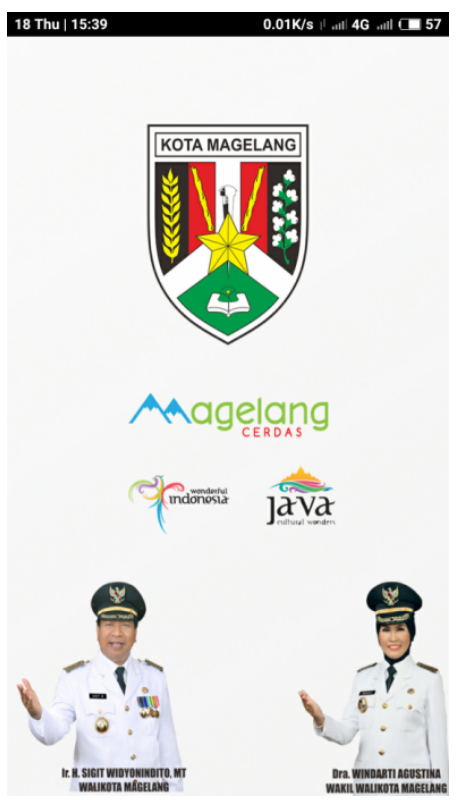

Gambar 3 Homepage aplikasi Android Kota Magelang

Sumber: aplikasi Android Kota Magelang, Desember 2017

Dalam aplikasi smartphone, logo dan tagline Magelang Kota Sejuta Bunga juga tidak dimunculkan, padahal logo untuk branding nasional dan provinsi di tampakkan. Pengoperasian aplikasi ini juga tidak bagus, ketika kita menekan satu tombol konten, konten tidak terbuka tapi aplikasi malah akan menutup dengan sendirinya. Magelang juga belum memasimalkan penggunaan media 
televisi dan radio. Media-media dalam kategori ini merupakan media-media yang di era seperti saat ini dirasa paling efektif, karena begitu dekat dengan keseharian manusia dan memiliki jangkauan yang luas.

b) Buletin dan rubik advertorial surat kabar

Majalah dan surat kabar memungkinkan untuk menjangkau audiens yang sangat bertarget. Kota Magelang belum memanfaatkan media ini, padahal wilayah pemerintahan terdekat, yakni Kabupaten Magelang sudah memanfaatkannya.

2) Media Lini Bawah

a) Baliho, billboard, umbul-umbul, roudtec, videotron

Semua media iklan diatas bisa dikatakan sama, yakni merupakan bentuk promosi iklan luar ruang dengan ukuran sedang hingga besar, yang diletakkan di tempat tertentu yang ramai dilalui orang. Di Kota Magelang, kategori media ini masih sedikit yang dipakai. Beberapa media promosi di dalam kategori ini yang di gunakan oleh Kota Magelang belum mencantumkan logo dan tampak tidak ada kesatuan konsep. Hal itu diakibatkan oleh belum adanya masterplan mengenai visual branding dan media promosi menyebabkan terhambatnya proses komunikasi.

\section{b) Poster indoor}

Media promosi ini dipasang di dalam ruangan. Untuk sebuah kota, poster ini bisa dipasang di public office, seperti perkantoran pemerintah, rumah sakit, terminal dan lain sebagainya. Kota Magelang belum mengaturnya secara baik, sehingga munculnya poster di beberapa kantor dinas di Kota Magelang dapat dikatakan sebagai inisiatif masing-masing kantor dinas. Tidak adanya acuan resmi yang menjadi standar pembuatan desain berdampak pada tidak terorganisirnya rancangan desain yang menggambarkan Magelang Kota Sejuta Bunga.

c) Car branding dan transit media

Jenis iklan yang bisa ditempatkan di berbagai transportasi umum atau di sekitar wilayah transportasi umum. Metode iklan ini bisa ditempatkan di sisi bus, kereta api, dan juga taksi. Bukan itu saja, tempat-tempat seperti stasiun bus, stasiun kereta merupakan tempat lainnya yang bisa juga dijadikan sebagai transit media. Media yang digunakan untuk pemasangan bisa mobil pemerintahan dan angkutan umum kota dalam bentuk ilustrasi cat atau stiker, dengan ukuran besar dan kecil. Salah satu keunggulan yang bisa didapatkan dari transit media adalah tingkat visibilitas yang tinggi dan banyak masyarakat yang melihat iklan produk. Kota Magelang belum memanfaatkan secara baik, sehingga munculnya mobil promosi milik beberapa kantor dinas di Kota Magelang dapat dikatakan sebagai inisiatif masing-masing kantor dinas. Tidak adanya acuan resmi yang menjadi standar pembuatan desain berdampak pada tidak terorganisirnya rancangan desain yang menggambarkan Magelang Kota Sejuta Bunga. Pemanfaatan transportasi umum yang ada di wilayah Kota Magelang juga belum dilakukan. Bahkan, logo Magelang Kota Sejuta Bunga juga belum terpasang di mobil pemerintahan maupaun transportasi umum.

d) Stasionery

Media promosi berupa peralatan kantor yang dicetak dan merupakan gambar yang harus didesain agar menarik dan 
menggambarkan citra perusahaan (kota), contoh: kartu nama, email template, kop surat, letter head, amplop, cover $C D$, member card, dan lain sebagainya. Pemerintah Kota Magelang belum menerapkan sama sekali media ini.

e) Sign system dan identity signature

Rangkaian representasi visual dan simbol grafik yang bertujuan sebagai media interaksi manusia dengan ruang publik. Dalam pengertian lainnya, sign system juga sebagai petunjuk bagi mereka yang membutuhkannya. Sign system harus mempunyai fungsi yang jelas dan efisien. Sign system di seluruh wilayah Kota Magelang belum ada yang merepresentasikan Magelang Kota Sejuta Bunga. Sign system dan identity signature sangat dibutuhkan mengingat batas wilayah pemerintahan Kota Magelang dengan wilayah Kabupaten Magelang berpotensi menimbulkan kerancuan. Ada beberapa batas wilayah Kotamadya dengan Kabupaten yang hanya berbatas jalan kecil, bukan yang jembatan, sungai, atau persimpangan besar.

\section{f) Merchandise}

Salah satu manfaat merchandise pada sebuah kota adalah untuk membuat konsumen senantiasa ingat dengan produk dan jasa yang disajikan oleh kota tersebut. Normalnya, sebuah merchandise kota seharusnya mencantumkan nama dan logo kota, sehingga setiap kali konsumen melihat merchandise promosi yang diberikan sebuah kota, mereka akan ingat produk dan jasa yang ada. Kota Magelang belum mempunyai merchandise khusus yang mewakili Magelang Kota Sejuta Bunga yang bisa dibawa pulang oleh wisatawan. Saat ini hanya jenis makanan getuk saja yang menjadi oleh-oleh khas Kota Magelang. Merchandise yang mewakili Magelang Kota Sejuta Bunga belum ada di Kota Magelang. Media ini bisa memanfaatkan pengusaha UKM yang ada di Kota Magelang, yang sekaligus berarti memajukan pengusaha kecil yang ada di wilayah Kota Magelang.

g) Peta wisata baik dalam bentuk kertas maupun papan, buku profil, katalog, atau brosur

Media ini sangat membantu wisatawan mendapatkan informasi ketika akan dan sedang berkunjung ke sebuah wilayah, sangat disayangkan Kota Magelang belum mempunyai media ini, padahal banyak potensi pariwisata yang bisa dikunjungi. Media aplikasi digital memang sudah mencantumkan konten ini, namun dengan masih kurang baik pengoperasiannya dan untuk menjaga keterbatasan jaringan internet, serta menjaga keluasan target yang dituju oleh Kota Magelang dalam mempromosikan kota, maka media dalam bentuk kertas maupun papan juga dibutuhkan.

Penempatan media juga penting karena mempelajari sebuah brand sama seperti mempelajari rute dari dari rumah ke satu tujuan tertentu yang sering dikunjungi. Kemampuan mengingat apa saja yang ada di sepanjang jalan tersebut merupakan pembelajaran yang tidak disadari. Semua terbentuk karena kebiasaan dan rentang waktu yang relatif panjang. Lynch (1960:47-p) telah menyatakan sebuah teori yang digunakan untuk pengukuran persepsi warga terhadap kota nya dengan menggunakan informasi yang didapatkan melalui obyek visual yang ada di suatu kota, teori tersebut menyatakan 
penduduk kota memahami lingkungan dengan membangun mental map yang terdiri dari 5 komponen.

1) Jalur (path): jalan, gang, jalan setapak dan saluran lainnya yang digunakan untuk bepergian. Jalur di Kota Magelang yang berpotensi ialah Jalan Tentara Pelajar, Sekitaran Rindam, Jalan Gatot Subroto, Jalan Pemuda, Jalan Nasional, Jalan Pahlawan, Jalan Jendral Sudirman, Jalan Mataram, Jalan Tidar, Jalan A. Yani.

2) Tepian (edges) yang dipersepsikan sebagai batas: dinding, gedung, garis pantai. Tepian di Kota Magelang yang berpotensi ialah Pintu masuk ke Kota Magelang dari segala penjuru: Jalan Raya Bandongan (Cacaban), Jalan Raya Magelang Purworejo (persimpangan Pakelan), Jalan Magelang-Yogyakarta (persimpangan Soka), Jalan Magelang-Salatiga (persimpangan Canguk), Jalan MagelangSemarang (Sambung).

3) Distrik: merupakan bagian yang relatif besar dari sebuah kota dan ditandai dengan identitas atau karakter tertentu. Distrik di Kota Magelang yang berpotensi ialah Pecinan, Alun-alun, Rindam, sepanjang Jalan Tidar, Pasar Rejowinangun, Bukit Tidar, sekitaran Universitas Negeri Tidar - Stadion Moch Soebroto.

4) Nodal / titik fokus: berupa simpangan atau lokasi tertentu. Nodal di Kota Magelang yang berpotensi ialah Cacaban, Persimpangan Pakelan, persimpangan Soka, persimpangan Canguk, Sambung, sekitaran Pasar Rejowinangun

5) Landmark yang merupakan objek yang dapat diidentifikasikan dan menjadi titik refrensi eksternal. Landmark di Kota
Magelang yang berpotensi ialah Alunalun, Taman Kyai Langgeng, Rindam, Taman Badakan, Bukit Tidar, Terminal Tidar, Pecinan, Kawasan Barkorwil, Museum-museum, dan obyek-obyek wisata yang ada di Kota Magelang.

\section{3) Activation}

Selain sebagai wadah untuk menciptakan komunikasi dua arah antara brand dan konsumen, brand activation juga berfungsi untuk membangun ketertarikan konsumen, misalnya saja lewat product experience dengan cara memberikan kesempatan bagi konsumen untuk mencoba produk atau jasa secara personal. Pengalaman biasanya diciptakan melalui edukasi, sehingga konsumen mau mengapresiasi brand. Dalam meenciptakan pengalaman itu, brand tentunya juga harus mampu membangun hubungan emosional dengan masyarakat sebagai konsumen. Semakin kuat hubungan emosional, maka interaksi pun akan lebih berkualitas, misalnya saja konsumen akan lebih sering lagi membeli produk atau berkunnjung. Pengalaman bisa diberikan melalui kegiatan exhibition, festival, bazar, dan lain sebagainya. Kota Magelang memiliki beberapa acara festival yang diadakan untuk memperkenalkan potensi yang dimiliki, namun festival tersebut tidak dilaksanakan secara rutin dan terus menerus. Brand activation membutuhkan intesitas melalui kegiatan yang dilakukan secara rutin dan terus menerus. Beberapa kendala yang dialami oleh Kota Magelang dalam melaksanakan brand activation yang memiliki intensitas tinggi ialah kurang kreatifnya konsep acara, sehingga tampak hampir sama acara-acaranya. Festival Magelang Kota Sejuta Bunga pernah dilaksanakan, namun hanya 
sekali saja dan konsep acaranya seperti tidak ada bedanya dengan karnaval dalam rangka HUT Republik Indonesia.

\section{SIMPULAN}

Di Kota Magelang logo secara resmi di pamerkan baru pada akhir Januari 2018, padahal program Magelang Kota Sejuta Bunga sudah di mulai sejak tahun 2012. Logo dari Kota Magelang belum bisa dikatakan mewakili filosofi dan tujuan dari Magelang Kota Sejuta Bunga. Unsur estetika berupa wujud logo belum mencerminkan filosofi dan tujuan program city branding Magelang Kota Sejuta Bunga. Warna menjadi masalah utama dalam logo tersebut, dominasi satu warna oranye hanya mewakili satu filosofi yaitu semangat Kota Magelang untuk terus bergerak maju. Unsur estetika bobot logo kurang kuat. Pesan yang coba disampaikan melalui logo kurang jelas karena pengaruh dari unsur wujud yang memang sudah kurang tepat, yakni perihal warna dan penempatan tulisan sejuta bunga yang mengakibatkan ukuran huruf harus kecil, sehingga tingkat keterbacaannya rendah. Unsur estetika penampilan logo masih kurang memaksimalkan jenis media-media promosi dan lokasi penampatan media promosi, sehingga proses komunikasi logo juga terhambat. Kurangnya media promosi dan lokasi penampatan media promosi yang dimanfaatkan mengakibatkan intensitas masyarakat untuk mendapatkan informasi dan pesan Magelang Kota Sejuta Bunga kurang dan dapat disimpulkan juga bahwa proses komunikasi logo khususnya, dan program Magelang Kota Sejuta Bunga pada umumnya berjalan kurang efektif.
Untuk membantu mensukseskan program city branding Magelang Kota Sejuta Bunga, kedepannya unsur estetika wujud, bobot dan penampilan logo magelang kota sejuta bunga sebaiknya lebih diperhatikan. Estetika mampu menimbulkan rasa senang, rasa puas, rasa aman, rasa nyaman dan ketika rasa itu sangat kuat, manusia yang menyaksikannya akan terharu, terpaku, terpesona, serta menimbulkan keinginan mengalaminya. Atau dengan kata lain persepsi visual yang estetis akan menimbulkan reaksi dari yang mengamati, sehingga si pengamat akan terpengaruh, kemudian melakuan perbuatan dan menghasilkan sesuatu yang menjadi tujuan sebuah karya visual, maka dari itu logo yang merupakan bentuk visual yang menjadi pemersatu dan pengikat pesan haruslah memenuhi kaidah estetika. Macam jenis warna lain sebaiknya di tambahkan di logo, penempatan tulisan sejuta bunga bisa diperbaiki, sehingga ukuran bisa lebih besar dan bisa diaplikasikan ke dalam berbagai media promosi dengan baik. Macam jenis media promosi juga diperbanyak dan dimaksimalkan untuk meningakatkan intensitas masyarakat memperoleh informasi dan tentunya memperlancar proses komunikasi.

\section{REFERENSI}

\section{Buku}

[1] Budiman, M. Arief. 2008. Jualan Ide Segar, Yogyakarta: Galang Press Yogyakarta.

[2] Djelantik, A.A.M. 1999. Estetika Sebuah Pengantar, Bandung, Masyarakat Seni Pertunjukan Indonesia Bandung. 
[3] Kotler dan Keller. 2009. Manajemen Pemasaran, Jilid 1 edisi ke 13, Jakarta, Erlangga Jakarta.

[4] Rakhmat, Jalaluddin. 2013. Psikologi Komunikasi. Bandung: PT Remaja Rosdakarya.

[5] Suparpto, Andi. (2016). Ada Mitos dalam D.K.V. (Desain Komunikasi Visual), Jakarta, PT Lintas Kreasi Imaji Jakarta.

[6] Tinarbuko, Sumbo. 2015. DeKaVe Desain Komunikasi Visual- Penanda Zaman Masyarakat Global, Yogyakarta, CAPS (Center for Academic Publishing Service) Yogyakarta.

[7] Yananda, M Rahmat dan Salamah, Ummi. 2014. Branding Tempat: Membangun Kota, Kabupaten dan Provinsi Berbasis Identitas, Jakarta, Makna informasi Jakarta.

[8] Majalah MIX edisi 20 September - 18 Oktobber 2016, Jakarta, PT SWA Media International Jakarta Pusat

\section{Jurnal}

[1] Anholt, S. (2007) "Competitive Identity: The New Brand Management for Nations, Cities and Region". London : Palgrave Macmillan.

[2] Lynch, Kevin. The Image of the City. Cambridge MA: MIT Press, 1960. 24 November 2017

[3] Suparta, I Made. (2007). Unsur-unsur visual, repo.isi-dps.ac.id. Pukul 13.50 WIB, 22 Agusutus 2017

[4] Suwardikun. W, Didit. (2000). Merubah Citra Melalui Perubahan Logo. Bandung, ITB Library. http://journals.itb.ac.id/, Pukul 10.27 WIB, 2 Februari 2018

[5] Tri Prasetyo Utomo. (2015). Estetika Kota dalam Tekanan Modernitas, Jurnal prosiding ISI Surakarta "mengeja rupa kota”, ISI press, Surakarta.
[6] Masterplan Magelang Kota Sejuta Bunga 2012. Magelang, BAPPEDA Kotamadya Magelang. http://magelangkota.go.id/, pukul 10.00 WIB, 1 Februari 2018. 